UDC 632.08: 634.4: 911.6

\title{
EVALUATION OF PHYTOSANITARY STATUS OF AGROCENOSES OF POME FRUITS OF THE CHERNIVTSI REGION
}

\author{
Yu. M. Bunduk \\ Ukrainian Scientific and Research Station for Plant Quarantine of the Institute of Plant \\ Protection of the National Academy of Agrarian Sciences, Boiany Village, Novoselytskyi District, \\ Chernivtsi Region, Ukraine; \\ e-mail: jbun@i.ua \\ Local selective phytovirological studies of plantations of pome fruits (apples, pears, \\ quinces) for the presence of chlorotic maculation virus of the leaves of apple tree, apple tree mosaic \\ virus, apple tree bark striation and pit virus in private and state agricultural enterprises of the \\ Chernivtsi Region with a total area of 135.05 ha were carried out. Based on the results of visual \\ local selective phytovirological studies, no signs of exposure to the studied viruses were found. The \\ results of selective studies were confirmed via diagnostics of studied samples by ELISA.
}

Key words: pathogens of viral diseases, phytovirological monitoring, pome fruits, enzyme immunoassay

In modern conditions, the prevalence and harm of the phytoviruses as a consequence of the emergence of new strains and the proliferation of untreated gardening material increases as a rule. Pathogens of viral diseases are characterized by high levels of harm: causing violations of physiological processes, inhibiting growth, resistance to environmental stress factors, survivability of buds, rooting and cutting in mother plants, increasing the susceptibility of the plants to fungal and bacterial diseases. The most harmful viruses, reducing generative productivity, can lead to losses of $20-70 \%$ of the crop [6].

For the laying of mother and industrial plantings of fruit crops, it is necessary to use gardening material treated from the main harmful viruses or tested that will increase the vegetative productivity of the mother plants and increase the yield of the gardens [7, 9].

The following viral and mycoplasmal diseases of pome fruits are known: apple - mosaic, proliferation, softening of apple tree, flat branches disease, green wrinkling of fruits, stellate cracking of fruits, small fruit size [1]; pears - ring mosaic, yellowing of the leaf ribs, pit of the wood, stoniness of fruits, dieback of pears [8].

In addition, a number of latent viruses were found on apple, pear, and quinces. Among them are chlorotic maculation virus of apple leaves, pit of the wood, dieback, and bark striation of wood 
$[2,5]$, which may be the cause of diseases in other fruit crops. For example, chlorotic maculation virus of apple leaves is a causative agent of pear ring mosaic, cherry fruit necrosis, cracking of the plum tree bark, apricot tree rosette, and mosaic ring spot of quince.

In virology and phytovirology in particular, there are many types and modifications of serological reactions that are used to diagnose, identify and detect viruses in pathological material, even in extremely small concentrations. These methods include enzyme immunoassay - one of the most sensitive serological methods for detection and identification of viruses irrespective of particle morphology [3].

Due to the fact that the development of horticulture in the Chernivtsi region is characterized by positive dynamics, the probability of defeat of fruit crops by pests and diseases, in particular viral, increases. That is why phytovirological monitoring of viral diseases to detect the damage to pome fruits with viruses is relevant.

Materials and methods. The study material included samples from the breeding-grounds of vegetative cuttings of Ukrainian Scientific and Research Station for Plant Quarantine of the Institute of Plant Protection; plants from test tubes that are in in vitro culture during the actual micropropagation stage, microclonal plants during root development.

Sampling was carried out from such types of quince as: Angers quince, sido quince, MC quince, quince BA29, IC 2 -10, IC 4-12, IC 4-6.

According to European conditions [10], study of agrocenosis was conducted from May to June, using young completely open leaves for the presence of apple tree mosaic virus (ATMV) and chlorotic maculation virus of apple leaves and apple on the old leaves for detection of apple tree bark striation and pit virus.

At routine inspections in gardens with an area of up to 100 ha, at least 50 trees of two or three district varieties of main breeds were inspected. Each tree was examined from 4 sides, especially from the north, where the symptoms are more clearly manifested and persisted longer in mother fruit planting. All mother trees with symptoms of diseases were marked with a bright oily paint [4].

Control of extension was carried out at the farms of Chernivtsi region. Routing selective inspections were performed in 5 districts of 9 farms of different forms of ownership using GPStechnology (GPS navigator GARMIN).

Table 1 provides the list of regions and inspected farms, as well as the area of plantings of pome fruits, in particular apples and pears. The total inspection area was 135.05 ha, of which apple plantations -128.05 ha and pears -7 ha. 
During phytovirological monitoring, samples of the following apple tree varieties were selected: Lisa, Florina, Chempion, Aidared, Jonathan Gold, Golden Delicious, Gloucester, Fuji, Renet, Symyrenka, and pear tree: Noiabrska, Snizhynka, Krupnoplidna.

Table 1. Phytovirological monitoring of agrocenoses of Chernivtsi region on the detection of viral diseases of pome crops

\begin{tabular}{|c|c|c|c|}
\hline \multirow{2}{*}{ Inspection district } & \multirow{2}{*}{ Agricultural farm } & \multicolumn{2}{|c|}{ Area of pome fruits planting, ha } \\
\hline & & apple tree & pea tree \\
\hline Kitsmanskyi & $\begin{array}{l}\text { Farm "Mishors" } \\
\text { Village of Dubivtsi }\end{array}$ & 10.45 & - \\
\hline Zastavnivskyi & $\begin{array}{l}\text { State Enterprise "Experimental Farm } \\
\text { of Prydnistovska Research Station of } \\
\text { Horiculture of the Institute of } \\
\text { Horiculture of the NAAS" }\end{array}$ & 5 & 2 \\
\hline \multirow{3}{*}{ Khotynskyi } & $\begin{array}{l}\text { Farm "Sharm" } \\
\text { Village of Nedoboivtsi }\end{array}$ & 13 & 2 \\
\hline & $\begin{array}{l}\text { Rural Farm "Gold-Sad" } \\
\text { Village of Dolyniany }\end{array}$ & 12 & - \\
\hline & $\begin{array}{l}\text { Farm "Maiak NIL" } \\
\text { Village of Dankivtsi }\end{array}$ & 40 & 1 \\
\hline \multirow{3}{*}{ Kelmenetskyi } & Agrarian Company "Dnistrovske", LLC & 10 & - \\
\hline & Agricultural cooperative "Babynske" & 25 & - \\
\hline & Farm "Kondratskyi" & 12 & 2 \\
\hline Novoselytskyi & $\begin{array}{l}\text { Ukrainian Scientific and Research } \\
\text { Station for Plant Quarantine of the } \\
\text { Institute of Plant Protection }\end{array}$ & 0,6 & - \\
\hline \multicolumn{2}{|r|}{ Totally } & 128.05 & 7 \\
\hline
\end{tabular}

Selected samples were tested for the presence of the following viruses: apple tree mosaic, chlorotic maculation virus of apple leaves, tree bark striation and pit virus.

Diagnostics of planting of pome fruits was carried out by the method of enzyme immunoassay (ELISA) using a test system manufactured by Loewe (Germany). Testing system reagents are optimized for DAS-ELISA analysis using certified plates (NUNC-ImmunoPlates MaxiSorp F96) with a working volume of wells of $200 \mu$ l.

The principle double antibody sandwich (DAS) ELISA is to ensure that the microwellspecific antibodies immobilized on the surface provide capture of the virus, which is identified if present in the sample. In the next step, the conjugate of specific antibodies with the enzyme is used to detect the captured virus. The presence of the enzyme is detected by a colorimetric substrate reaction. 
Testing of the test samples was carried out in May and June, as it was established that during this period, the maximum amount of viral particles is accumulated in plants [10]. The repetition of the experiment is two-time.

Results and discussion. Despite the fact that the manifestation of symptoms varies depending on the pathogen, genotype of the plant, climatic and other factors, the primary method of diagnostics of viral diseases of plants is a method of evaluation of external signs. Data obtained from the visual examination of the plant, allow us to conclude on the nature of the disease.

The clone grafts of ordinary quince plants under introduction have shown high sensitivity to the infection of an apple tree mosaic virus. In total, 84 samples were tested, 28 of them - from vegetative grafts breeding grounds, and the same amount - at the stage of micropropagation and rooting.

It was revealed that Angers quince and sido quince were found to be infected with the tested virus in $20.0 \%$ and $5.0 \%$ among samples selected from breeding grounds of vegetative grafts, respectively. As a result of treatment of plants by tissue culture method in combination with thermo- or chemotherapy upon in vitro diagnostics of culture at the stage of micropropagation, the number of infected plants of ordinary quince decreased and was $5 \%$ for samples of Angers quince and $2 \%$ for samples of sido quince from the total number of studied samples (Table 2).

Table 2. Estimation of baseline and treated quince clones for the presence of an apple tree mosaic virus (by ELISA method)

\begin{tabular}{|l|c|c|c|}
\hline \multirow{2}{*}{ Type of vegetative grafts of quince } & \multicolumn{3}{|c|}{ Number of infected samples, \% } \\
\cline { 2 - 4 } & $\begin{array}{c}\text { breeding } \\
\text { grounds of } \\
\text { vegetative } \\
\text { grafts }\end{array}$ & $\begin{array}{c}\text { at the stage of } \\
\text { micropropagation }\end{array}$ & $\begin{array}{c}\text { at the stage of } \\
\text { rooting of micro } \\
\text { sprouting }\end{array}$ \\
\hline Angers quince & 20.0 & $5.0-$ & - \\
\hline Sido quince & 5.0 & 2.0 & - \\
\hline MC quince & - & - & - \\
\hline BA 29 quince & - & - & - \\
\hline IC 2-10 & - & - & - \\
\hline IC 4-6 & - & - & - \\
\hline IC 4-12 & - & - & - \\
\hline
\end{tabular}

Upon the diagnostics of ordinary quince for the presence of ATMV, no positive result was found suggesting the efficacy of the treatment measures for ordinary quince clones in the process of microclonal propagation.

Subsequent studies aimed at diagnostics of samples of various types of quince for other viral diseases. 
As a result of the visual inspection at Agrarian Company "Dnistrovske", LLC on the apple tree variety Golden Delicious, samples with symptoms of chlorotic maculation and deformation of the leaf plate, which is characteristic for the infection of the chlorotic maculation virus of apple leaves (fig.) were detected.

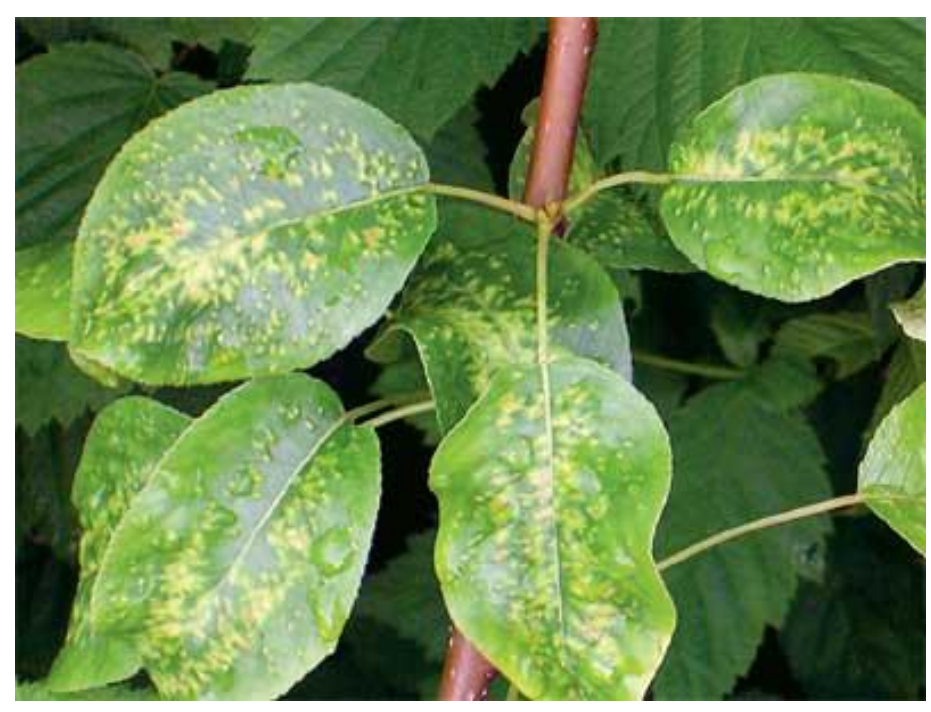

Fig. Sample of apple tree of Golden Delicious variety (Agrarian Company “Dnistrovske”, LLC)

However, during an enzyme immunoassay analysis, negative results were obtained on the samples tested.

According to the results of diagnostics for the presence of mosaic viruses, chlorotic maculation of apple leaves, apple tree bark striation and pit by ELISA method, it was found that all the samples tested showed the absence of the above listed pathogens of viral diseases. In total, this method detected 400 samples for the presence of each of the tested viruses separately.

Thus, the diagnostics of the involvement of pome fruits (apple, pear, quince) obtained by microclonal propagation methods, mosaic virus, chlorotic maculation of apple leaves, apple tree bark striation and pit in the farms and state farms of the south-western region of Ukraine by the method of ELISA revealed the above listed pathogens.

The results of studies suggest the necessity of introducing a system of propagation of certified seedlings for the purpose of further massive planting and reproduction of intensive type gardens. 
1. Власова О. Шкідники та хвороби яблуневого саду / О. Власова // Агробізнес сьогодні. - № 5 (252). - 2013. - С. 28-32.

2. Воронин Е. И. Вирусные и микоплазменные болезни плодовых культур в Крыму / Е. И. Воронин // Труды прикладной ботаники, генетики и селекции. - Т. 59, Вып. 2. - 1997. - C. 147-152.

3. Мельничук М. Д. Фітовірусологія / М. Д. Мельничук. - К. : Поліграф Консалтинг. $-2005 .-200 \mathrm{c}$.

4. Облік шкідників і хвороб сільськогосподарських культур / [В. П. Омелюта, І. В. Григорович, В. С. Чабан та ін. ] ; за ред. В. П. Омелюти. - К. : Урожай. - 1986. — 296 c.

5. Пересыпкин В.Ф. Болезни сельськохозяйственных культур: в 3 т. / В. Ф. Пересыпкин // Болезни овощных и плодовых культур. - К. : Урожай, 1991 - Т. 3. — $208 \mathrm{c}$.

6. Проблеми моніторингу у садівництві / за ред. А. М. Силаєвої. - К. : Аграрна наука, 2003. - $346 \mathrm{c}$.

7. Технология получения сертифицированного посадочного материала плодовых и ягодных культур: методические указания / [А. А. Борисова, М. Т. Упадышев, Н. Н. Мельникова и др.] - М. : ФГНУ «Росинформагротех». — 2009. - 84 с.

8. Упадышев М. Т. Вирусные болезни на груше / М. Т. Упадышев // Защита и карантин растений. - 2008. - № 4. - С. 55-56.

9. Упадышев М. Т. Диагностика вирусов семечковых и косточковых культур методами ИФА и ПЦР / М. Т. Упадышев, Н. Н. Мельникова, А. Д. Петрова. - М. : ВСТИСП, 2008. -35 c.

10. European conditions. Plant Viruses Online: Descriptions and Lists from VIDE Database. $-1996$. 


\section{ОЦЕНКАФИТОСАНИТАРНОГО СОСТОЯНИЯ АГРОЦЕНОЗОВ \\ СЕМЕЧКОВЫХ ПЛОДОВЫХ ЧЕРНОВИЦКОЙ ОБЛАСТИ}

\author{
Ю. М. Бундук
}

Украинская научно-исследовательская станция карантина растений Института защиты растений НААН, с. Бояни, Новоселицкий р-н, Черновицкая обл.

Проведены локально-выборочные фитовирусологические исследования насаждений семечковых плодовых (яблони, груши, айвы) на наличие вируса хлоротической пятнистости листьев яблони, вируса мозаики яблони, вирусов бороздчатости и ямчастости коры яблони в частных $u$ государственных сельскохозяйственных предприятиях Черновиикой области общей площуаью 135,05 га. По результатам визуальныхх локально-выборочных фитовирусологических исследований не определень признаки поражения исследуемыми вирусами. Результатьл выборочных исследований подтверждены с помощью диагностики исследуемых образиов методом ИФА.

Ключевые слова: возбудители вирусных болезней, фитовирусологический мониторинг, семечковые плодовые, иммуноферментный анализ

\section{ОЦНКА ФІТОСАНІТАРНОГО СТАНУ АГРОЦЕНОЗІВ ЗЕРНЯТКОВИХ ПЛОДОВИХ ЧЕРНІВЕЦЬКОЇ ОБЛАСТІ}

\author{
Ю. М. Бундук
}

Українська науково-дослідна станція карантину рослин Інституту захисту рослин НААН,

с Бояни, Новоселицький р-н, Чернівецька обл.

Проведено локально-вибіркові фітовірусологічні обстеження насаджень зерняткових плодових (груша, яблуня, айва) на наявність вірусу хлоротичної плямистості листків яблуні та вірусу мозаӥки яблуні, вірусів борозенчатості та ямкуватості деревини яблуні у приватних та державних сільськогосподарських підприємствах Чернівеиької області загальною площеюю 135,05 га. $3 a$ результатами візуального локальновибіркового фітовірусологічного обстеження не виявлено ознак ураження досліджуваними вірусами. Результати вибіркових досліджень підтверджені за діагностування досліджуваних зразків методом IФА.

Ключові слова: збудники вірусних хвороб, фітовірусологічний моніторинг, зерняткові плодові, імуноферментний аналіз 